\title{
Research of Enterprise Cost Control Based on Target Cost Management
}

\author{
Yi Zhang \\ Xinyu University \\ Xinyu, China 338004
}

\begin{abstract}
With the development of China's economy, market competition is becoming increasingly fierce. To gain a foothold in the fierce market competition, enterprises should conduct financial management effectively. Target cost management occupies an important position in the financial management. The effect of cost control directly affects the enterprise project success, so it is vital for enterprises to introduce advanced cost control technology in the process of the actual financial management, thus promoting the sound enterprise development. In the paper, first of all, the enterprise target cost management is overviewed. Secondly, the enterprise cost control measures based on target cost management are discussed. Finally, the application of enterprise cost control based on target cost management is analyzed. It is hoped that the research results can provide valuable reference for others.
\end{abstract}

Keywords-target cost management; enterprise cost; enterprise management

\section{INTRODUCTION}

At present, increasing number of new companies and business attend the market competition in China. Under fiercer and fiercer market competition environment, the main influencing factor of enterprise development is the ineffective cost control of internal operation projects, and insufficient application of cost control. In the process of enterprise development, the traditional cost management modes can't effectively control the enterprise cost. In order to effectively change the present situation, enterprises should regard target cost management as the core, control enterprise operation cost through forecast analysis, planning and control methods, reduce the property risks of enterprises, and fully play the economic benefits of the enterprises.

\section{ENTERPRISE TARGET COST MANAGEMENT}

\section{A. The Concept of Target Cost Management}

The concept of target cost management is based on target management, so target cost management can also be understood as the target management of cost. Target cost management refers to the a series of cost management work based on enterprise budget, including analysis of enterprise management target, the study, the evaluation, and assessment of target cost on the basis of cost forecast, cost decisionmaking, and the determination of target cost. In the process of enterprise operation, enterprise staff needs to understand the importance of target cost, avoid confusing cost target with enterprise target, and should be able to separate them so as to, more effectively control and manage the actual cost. As for target cost management, the core is management; the means is budget; the purpose is benefit. It involves the cost forecast, analysis, and control in advance and post-action assessment of cost control. China's enterprises should adopt prior control of cost management, rather than post-action control, develop a clear goals for the cost control, form a cost control system of the whole enterprise, the whole process, and staff, make full play of the enterprise economic benefit, and effectively improve the cost management level of enterprises [1].

\section{B. Principle of Target Cost Management}

Generally speaking, if a buyer's estimates of product price is higher than the product itself value, this product will sell well. Therefore, enterprises not only should meet customers' requirements for product price, but also make the product cost be lower than the retail price of the product in the process of trade. The bigger differences between product cost and product price, the more economic benefits the enterprises will gain. Hence, when controlling cost, enterprises must investigate and analyze the market economy, determine the target cost on the basis of deducting profits, and ensure the actual cost be lower than the target cost. Once the actual cost exceeds the target cost, enterprises will gain less profit, thus facing economic losses.

In order to maximize the interests, enterprises need to analyze the principles of target cost management. General target cost management consists of the following principles: price-driven costing, the focus on customers, the focus on product and process design, cross-functional cooperation, and the participation of value chain. Price-driven costing: target cost management system determines the target cost management through the analysis of market price expectations and on the basis of market price minus the company profits. General market price is determined according to the external market competition situations, and the target profit is determined by the internal financial situation of the enterprise. The focus on customers: the main driving force of target cost management system is the market; in the process of product design and decision-making, enterprises should analyze the needs of customers, such as customer demand for product quality and price, and then conduct target cost management. The focus on product and 
process design: before the production of products, enterprises first need to conduct product design, which needs to invest a lot of time. Enterprises can control the product design process using process design and the new means of design. Additionally, enterprises also need to delete some timeconsuming steps without design value, and ensure products can be put into the market faster. Cross-functional cooperation: under the target cost management system, each department of one enterprise cooperates, and is responsible for enterprise products. The participation of value chain: target cost management process requires the participation of value chain, which includes many members, such as suppliers, wholesalers and retailers. Only by following the principles of the target cost management, can enterprises effectively control cost [2].

\section{The Characteristics of Target Cost Management}

In the first place, target cost management lays emphasis on the participation of all staff and the realization of optimal allocation of resources, which reflects the people-oriented characteristics. Furthermore, target cost management is also comprehensive and systematic. Target cost management is an important part of the cost control system, so adopting the management idea can implement comprehensive cost control to enterprise department and class. Besides, target cost management is closely linked to other management targets within the enterprises. We should combine target cost management with quality management, schedule management, security management, and form systemic target cost management so as promote the balanced development of enterprises. Moreover, target cost management also has the characteristics of comprehensiveness and profitability. As for profitability, under the target cost management system, enterprise should regard the improvement of internal economic benefits of enterprises as a starting point, maximize profits. Its comprehensiveness is mainly embodied in two aspects, namely, comprehensive management method, target cost management and comprehensive integration of other management [3].

\section{ENTERPRISE COST CONTROL MEASURES BASED ON TARGET COST MANAGEMENT}

\section{A. To Raise Enterprise Personnel's Awareness of Cost Control}

To strengthen the enterprise staff's awareness of cost control is the premise that enterprises can complete cost control and carry out the target cost excellently. Enterprises need to establish a distinctive work team, which should include the sales department, financial management department, accounting department, so as to conduct cost management target oriented cost control. To raise enterprise personnel's awareness of target cost control, enterprise can provide new and old staff with regular targeted trainings of the target cost management concept, connotation and significance by inviting training instructors with stronger professional ability, and employees with high comprehensive quality. In addition, enterprises can promote target cost management concept by making use of official platform so as to strengthen the enterprise staff's awareness of target cost control. Besides, enterprises can establish corresponding appraisal mechanism, test the results of the trainings, and link the assessment results to employee performance, with good performance, give corresponding rewards, such as salary and extra holiday for employees with stronger awareness of target cost control, and give proper criticism education for employees with worse performance, so that each employee can realize the importance of target cost control work, and create a good working environment [4].

\section{B. To Make Scientific Target Cost Control Plans}

As mentioned above, target cost is identified by the product selling price minus the target profit and tax. To make scientific target cost control plans, first of all, enterprises should make targeted market researches to understand customer needs and preferences, and customers' foremost concerns (product quality or price, design or other aspects). In the second place, enterprises need to analyze and study the market information, adjust the products accordingly, win customer recognition and improve their market competitiveness. Meanwhile, enterprises also need to establish the corresponding feedback system using the advanced Internet technology, accept customers' feedback, and then make targeted modification of products, set the right price according to the market in the process of improvement, develop reasonable target cost control plans, and ensure to obtain the maximum economic benefits [5].

\section{To Perfect the Management System of Target Cost Control}

Sound system of target cost control management can provide legal basis for the enterprise cost control activities. Before perfecting the system of target cost control management, enterprises should formulate strict cost control regulations. First of all, enterprises need to refine the work of target cost, and strengthen the coordination of various departments in this process. Various departments should complete the statistics and analysis work of the enterprise production operation data and then accurately express them, make each department mutually coordinate and restrict when cost controls forms. In addition, enterprises need to compare the actual cost of their internal production and operation with the target cost, find out the causes if the actual cost is higher than target cost, and provide improvement direction for the future cost control. Secondly, to improve the enterprise cost control management system, enterprises need to establish long-acting risk management mechanism, consider long-term interests, actively prevent potential internal risks, and fully exert their operating efficiency.

\section{To Strengthen the Supervision System of Target Cost Control}

To improve the supervision system of target cost control, enterprises should supervise management personnel's performance, and the key links in the cost control. In the process, and enterprises need to figure out whether each department cooperates; for example, whether the sales department provides product market demand; whether the 
design department provides design idea; whether the purchasing department discusses the target cost. In the second place, enterprises can also conduct social supervision using the external forces such as government and related organizations, so as strengthen the target cost control. Strengthening target cost control system can help to analyze and evaluate the effect of the enterprise cost control, and effectively avoid the formal target cost control [6].

\section{E. To Establish Sound Information Management System}

When conducting target cost control, enterprises need to collect all kinds of basic data, survey and analyze information, which is the basis of their target cost control. Information contents include many aspects, such as product pricing and competitor information, cost data, customer demand information and data information of suppliers. To ensure the authenticity and accuracy of the information, enterprises shall establish sound information management system. Therefore, a sound management system decides the success of target cost control.

\section{THE APPLICATION ANALYSIS OF ENTERPRISE COST CONTROL BASED ON TARGET Cost MANAGEMENT}

\section{A. Application of Prior Control of Enterprise Cost}

As for prior cost control, enterprises need to discuss the influence and necessity of implementing target cost management cost control, and divide the working process and specific duties of working tasks, ensure staff has clear responsibilities. In addition, enterprises also need to establish an early warning system for deviation and feedback system, control cost management risks in advance, solve problems arising from the cost control at source, and make full play of the enterprise economic benefits.

\section{B. The Application of In-process Control of Enterprise Cost}

In-process control of enterprise cost is the key link of target cost management, and reasonable methods are needed. In the prior control, enterprises have established the corresponding deviation warning system; in the in-process control, enterprises need to analyze the causes of the deviation, adjust the corresponding main responsibility communicate and coordinate with relevant management personnel, formulate the corresponding solutions, and send solutions to each department units, who should carry out the corresponding work in time according to the solutions. Furthermore, in case of inevitable some sudden events in the production and business operation activities, enterprises' actual cost will be considerably different from the target cost, so the management personnel need to predict the risk points and the probability of reoccurrence, and then optimize the internal production process, and effectively avoid unexpected events [7].

\section{The Application of Post-action Control of Enterprise Cost}

Enterprise target cost management run through all links. After obtaining corresponding interests, enterprises still need to conduct post-action cost control so as to summarize the experiences of target cost management, explore whether there is a deficiency in the enterprise target cost management, and whether they need to optimize the process, technology, management, etc. Additionally, enterprises must establish the corresponding information feedback system and expression mechanism, let employees to express their views and opinions, and ensure the staff gets involved in the target cost management. Apart from the opinions of the employees, enterprises also need to collect and summarize customer feedback, make corresponding changes of target cost according to the opinion of the customers and their actual situations. Thus, it can be seen that post-action cost control has important practical significance for enterprises [6].

\section{CONCLUSION}

To sum up, enterprise cost control based on target cost management is very important to the development of enterprises. Relevant departments should first attach great importance to it, need to understand the connotation, principles and characteristics of target cost management. Besides, it is advisable for them to adopt various measures (to raise enterprise personnel's awareness of target cost control, to formulate scientific target cost control plans, to establish sound target cost control management system, to enhance the supervision system of cost control) to strengthen the enterprise internal control. Finally, they should analyze the prior control, in-process control and post-action control of enterprises based on target cost management so as to lay a good foundation for the enterprise development.

\section{REFERENCES}

[1] Jiang Qiaoyun. Application Research of Strategic Cost Management New High-tech Enterprises [J]. Money China (academic), 2015, 22 (4): 101 102.

[2] Qin Wenjuan. Application Research of Cost Management System in Manufacturing Enterprises based on Target Cost [J]. Journal of Economic \& Trade, 201501 (12): 367.

[3] Mileham A R, Currie G C, Miles A W, et al. A parametric approach to cost estimating at the conceptual stage of design [J]. Journal of EngineeringDesign, 1993, 4 (2):117 125

[4] Wang Qin. The Application Analysis of Target Cost Management in Enterprise Economic Management [J]. Economic Research Guide, 2015, 11 (02): 22 23.

[5] Zhao Lu. The Application Analysis of Target Cost Management in Enterprise Economic Management [J]. Journal of Macroeconomic Management, 2017 (S1)

[6] (American) Edward J. Bloch, Kang, H. Chen, Thomas W. Lin. Cost Management -Operation Control and Management Control [M]. Beijing: Huaxia Publishing House, 2012.

[7] Wu Xuelin. Target Cost Management [M]. Beijing: Economic Science Press, 2006:23 45.

[8] Jiang Feiran. How to effectively Apply Target Cost Management in Enterprise Economic Management [J].Money China, 2011 (02). 